\title{
The Influence of Shopping Motives and Store Attributes on Purchasing Decisions at Matahari Department Store Karawang
}

\author{
Dedi Mulyadi \\ Management Study Program, Faculty of Economics and Business, Buana Perjuangan University, \\ Karawang, Indonesia \\ Corresponding author email: dedi.mulyadi@ubpkarawang.ac.id
}

\begin{abstract}
This study aims to determine how much influence the shopping motives and store attributes on purchasing decisions at Matahari Department Store Karawang. The method used in this research is descriptive and verification. In this study, there are independent variables and dependent variables. Independent variables are variables that influence or cause the change or the emergence of the dependent variable. Meanwhile, the dependent variable is the variable that is influenced or becomes the result, because of the independent variables. The independent variables in this study are shopping motives and shop attributes, while the dependent variable is the purchase decision. In this study, the population is the number of consumers who have made purchases at Matahari Department Store Karawang for 1 month. The average number of consumers per week is 10,000 people. So to find out the number of consumers for 1 month by adding up the average consumer per week $/ 7$ x 30. (10,000 / 7) X 30, thus the results obtained are $42,857$. Keywords---purchase decision, shopping motive, store attributes.
\end{abstract}

\section{Introduction}

The increasing number of retail companies in Indonesia, making the competition more competitive. Therefore the company must develop the right marketing strategy to win the competition. One of them is by understanding consumer behavior. The development of consumer needs at retailers, from just shopping to recreational needs and social relations, confronts retailers that they must be able to understand the behavior of consumers who are their target market. Today's consumers are more rational, smart, and assertive in making shopping decisions and want the best service. So that consumers become increasingly difficult to meet their needs and it is increasingly difficult to be loyal by only shopping at one retailer. The requirements that must be met by a retail company to be successful in the competition are trying to achieve the goal of creating and retaining customers, to achieve these goals the company must be able to understand consumer behavior in its target market (Utami, 2010). If a company wants to keep running and continue to grow, then it must be able to attract new customers and retain customers who have become its customers, the task will be easier if business people understand consumer behavior well (Sumarwan, 2011).

According to (Sumarwan, 2011) consumer behavior is an action that is directly involved in obtaining, consuming, consuming a product or service, including the decision process that precedes it. Consumer behavior can be understood through marketing stimuli and environmental awareness of buyers as well as buyer characteristics and decision-making processes that then result in certain purchasing decisions (Jackson et al., 2011; Stoel et al., 2004). Companies or marketers must know each stage that consumers go through in buying a product so that consumers will be interested in the product being offered. The process of consumer purchasing decisions goes through the stage of problem recognition, information search, evaluation of alternatives, purchasing decisions, and post-purchase behavior (Kotler, 2007). The buying process begins when the buyer recognizes a problem or need. Consumers who are aroused by their needs will be motivated to seek more information. Then consumers will evaluate the choice of products and brands, and choose according to what consumers want and need. Consumers begin to intend to buy the brand they like best among these choices. After the purchase, consumers will re-evaluate whether the product they bought is following 
expectations or not. Consumer purchasing decisions have basic considerations that are influenced by internal and external factors such as buying motives and shop attributes (Wong et al., 2012; Sutisna, 2003).

Buying motives are something that encourages a person's behavior or attitude to go to a shopping place. The shopping motive is based on the needs and targets that have been formed by consumers (Kotler, 2008). Motivation arises because of a need that is felt by consumers, that need arises because consumers feel the discomfort (state of tension) between what should be felt and what is felt, the perceived need encourages someone to take action to meet those needs (Sumarwan, 2011).

The shopping motive plays an important role in purchasing decisions. If consumers have a strong desire and urge for a particular product, it can be an impetus to make a purchase decision. In research (Dearma, 2011), shows that the shopping motive is the most dominant variable affecting consumer purchasing decisions. Consumers have different motives when shopping (Eastlick \& Feinberg, 1999; Hunneman et al., 2017). The shopping motive itself consists of utilitarian shopping motives and hedonic shopping motives. The utilitarian shopping motive encourages consumers to buy products because of the functional benefits and objective characteristics of the product. Utilitarian motives are also referred to as rational motives (Solomon, 2004). While hedonic shopping motives, psychological needs such as satisfaction, prestige, emotions, and other subjective feelings. This need often arises to meet social and aesthetic demands. Hedonic motifs are also called emotional motives.

The store attribute is a characteristic that is owned by a store. In line with the development of people's lifestyle needs that increasingly want the convenience of shopping, price certainty, and the diversity of goods needed in a store, consumers demand retailers or stores to improve both in terms of management, store appearance, and service methods (Foster, 2008). Shop attributes include shop facilities, service convenience, shop atmosphere, price appropriateness, and completeness of goods. A store that has good attributes will encourage consumers to stay longer and will attract consumers' desire to know everything and finally make a purchase decision. In research (Azizi, 2008), shows that store attributes have a significant effect on consumer behavior in shopping.

Department store is modern retail which is quite developed these days. Department Stores provide a wide shopping area and the flexibility to choose products, a variety of goods of various sizes, a well-managed management system that offers shopping convenience, sells at fixed prices, and always holds discounts or promos. Compared to other types of retail, there are no fewer department stores. The following are department store outlets in Indonesia.

Table 1

Department store outlets in Indonesia in 2019

\begin{tabular}{llllll}
\hline No & Store Name & No & Store Name & No & Store Name \\
\hline 1 & Alun-Alun Indonesia & 22 & JM plaza Dept. Store & 43 & Lotte Shopping Avenue \\
2 & Asia Toserba & 23 & Keris Dept. Store & 44 & Ramayana Dept. Store \\
3 & Barata Dept. Store & 24 & Lima cahaya & 45 & Rimo \\
4 & Borma Dept. Store & 25 & Mark \& Spencer & 46 & Rita Dept. Store \\
5 & Borobudur Dept. Store & 26 & Matahari Dept. Store & 47 & Roberta Dept. Store \\
6 & Cahya Dept. Store & 27 & Mega Dept. Store & 48 & Robinson Dept. Store \\
7 & Center Dept. Store & 28 & Metro Dept. Store & 49 & Sahabat \\
8 & Centro Dept. Store & 29 & Mirota & 50 & Samudra Dept. Store \\
9 & Citra Niaga Dept. Store & 30 & Mutiara Cahaya & 51 & Sarinah Dept. Store \\
10 & Citrus Dept. Store & 31 & New Fashion & 52 & Seibu \\
11 & Debenhams & 32 & New Frida Store & 53 & Sinar Busana \\
12 & Diamond Dept. Store & 33 & New Harapan Baru & 54 & Sogo \\
13 & Edi Dept. Store & 34 & New Tiara Dept. Store & 55 & Star Dept. Store \\
14 & Esa Genangku & 35 & Pante Pirak Pasaraya & 56 & Sumber Karya Indah \\
15 & Gajah mada Dept. Store & 36 & Pasadena & 57 & Surya Toserba \\
16 & Galeries Lafayette & 37 & Pasaraya Blok M & 58 & The Goods Department \\
17 & Galleria & 38 & Pasaraya JM & 59 & Tiara Dept. Store \\
18 & Gardena Dept. Store & 39 & Pasaraya Sri Ratu & 60 & Variety Dept. Store \\
19 & Golden Trully & 40 & Pasaraya Yogya Kepatihan & 61 & Yogya Dept. Store \\
20 & Griya Dept. Store & 41 & Plaza Mode & 62 & Yuki - and etc. \\
21 & Isetan & 42 & Pojok Busana & & \\
\hline
\end{tabular}

Source: http://www.muamalatbank.com/assets/pdf/lain-lain/informasi_promo_subsidi_belanja

_20_persen_website_v2.pdf 
Table 1 above shows that in 2013 there were more than 62 names of department store outlets spread across all cities in Indonesia. This number will increase if calculated based on the number of outlets owned by each retail company. This is because the company does not only have one outlet.

Matahari Department Store is the largest and well-known retailer in Indonesia and has played a major role in introducing the department store concept in Indonesia since 1972. Currently, Matahari is known as the market leader in selling fashion apparel, accessories, and beauty products in the department store segment. Matahari already has 116 outlets in more than 50 cities in Indonesia, and one of them is in the city of Karawang.

Matahari Department Store Karawang is a choice for the Karawang community in shopping. In addition to its strategic location, the goods sold are also very diverse and of high quality, and the cleanliness and shop facilities provided make consumers feel comfortable in the shop. This is done by MDS Karawang to provide shopping facilities that support providing comfort to consumers when shopping. But in its implementation, there are still several service facilities that are complained of by MDS Karawang consumers, for example, MDS Karawang does not have a large parking area so that consumers who bring vehicles have difficulty finding a parking space, and often don't visit after seeing a full parking lot Next is the outlet layout that is too narrow and makes it difficult for customers to move when shopping, consumers also complain about the transaction process that cannot immediately pick up goods at the cashier and must return to pick up goods at the counter, and consumers do not feel comfortable when they have to be accompanied by a salesperson when choosing a product. Also, MDS advertising through the media is still lacking so that consumers do not know about the latest products and sales promotions.

This consumer complaint, of course, must get attention from the company because this indicates customer discomfort when shopping. The inconvenience is likely to make consumers switch to other retailers, this can be shown from the average visitors per week of MDS Karawang compared to its main competitors in Karawang.

Table 2

Visitors to Matahari, Ramayana, and Borobudur Karawang

\begin{tabular}{lll}
\hline No & Retail Name & Number of visitors \\
\hline 1 & Borobudur & 30.000 \\
2 & Ramayana & 20.000 \\
3 & Matahari Dept. Store & 10.000 \\
\hline \multicolumn{2}{l}{ Source: Radar Karawang, 12-04-2019, 24-08-20118, 01-08-2018 }
\end{tabular}

Table 2 above shows that MDS Karawang has an average number of visitors of 10,000 people per week. This number is the least when compared to Borobudur and Ramayana, where the average visitors are 30,000 and 20,000 people per week, respectively.

MDS Karawang should be able to resolve complaints and provide comfort for its customers to encourage their shopping intentions. MDS Karawang must understand the motives of its consumers when shopping, and complete store attributes that can create competitive advantage so that it will be a consideration for consumers in making purchases. Based on the description above, the researcher is interested in conducting a study entitled "The Influence of Shopping Motives and Store Attributes on Purchasing Decisions at Matahari Department Store Karawang".

\section{Research Methods}

This research uses descriptive and verification research methods. According to (Sugiyono, 2013) descriptive research is research conducted to determine the value of the independent variable, either one or more (independent) variables without making comparisons, or connecting with other variables. Meanwhile, verification research according to (Sugiyono, 2013), is a research method used to examine a specific population or sample, and data analysis is statistical to test predetermined hypotheses. The descriptive method in this research includes descriptive research. Correlation research according to Umar (2005) is a study designed to determine the level of the relationship between independent variables and the dependent variable and the magnitude of the direction of the relationship/influence that occurs.

The descriptive method is used to present the incoming data by grouping and tabulating, then the results are explained. The descriptive method is used to determine the description of shopping motives, store attributes, and purchasing decisions. While the verification method is used to measure a research phenomenon using statistical tools. The statistical method used to analyze the relationship between the variables studied is by using path analysis to test the effect of partially / individually and as a whole from the independent variables on the dependent variable. 
In this study, there are independent variables and dependent variables. Independent variables are variables that influence or cause the change or the emergence of the dependent variable. While the dependent variable is the variable that is affected or that is the result, because of the independent variable (Sugiyono, 2012). The independent variables in this study are shopping motives and store attributes, while the dependent variable is the purchase decision. In this study, the population is the number of consumers who have made purchases at Matahari Department Store Karawang for 1 month. The average number of consumers per week is 10,000 people. So to find out the number of consumers for 1 month by adding up the average consumer per week / 7 x 30. (10,000/7) X 30, thus the results obtained are 42,857 . Then the population in this study was 42,857 people. By using an error rate of $5 \%$ in a population of 42,857 people, the sample obtained was 346 respondents.

Determination of the number of samples in this study refers to determining the number of samples from the population developed by Isaac and Micheal. The calculation of the number of samples using the formula of Sugiyono (2012) is as follows:

Annotation:

$$
S=\frac{\lambda^{2} \cdot \text { P. N.Q }}{d^{2}(N-1)+\lambda^{2} \cdot \text { P.Q }}
$$

$\mathrm{S}=$ number of samples

$\lambda^{2}=$ with $\mathrm{dk}=1$

Error level up to $1 \%, 5 \%$, and $10 \%$.

$\mathrm{P}=\mathrm{Q}=0,5$ and $\mathrm{d}=0,05$

While the data collection techniques used, observation, interviews, and questionnaires were distributed to people who would be used as research samples.

\section{Research Result}

\section{The magnitude of Relationship between Independent Variables}

In path analysis, the relationship between the independent variables has a meaningful relationship, it aims to determine the amount of direct and indirect influence. The indirect effect is the product of the path coefficient and its correlation coefficient. Therefore, it is important to know the relationship between the two independent variables. The relationship between the two independent variables in this study can be explained in Table 3.

Table 3

Correlation between Shopping Motives $\left(\mathrm{X}_{1}\right)$ and Store Attributes $\left(\mathrm{X}_{2}\right)$

\begin{tabular}{|ll|l|l|}
\hline \multicolumn{2}{|l|}{ Correlations } & Shopping Motives & Store Attributes \\
\hline Shopping Motives & Pearson Correlation & 1 & $.642^{* *}$ \\
& Sig. (2-tailed) & & .000 \\
& $\mathrm{~N}$ & 346 & 346 \\
\hline Store Attributes & Pearson Correlation & $.642^{* *}$ & 1 \\
& Sig. (2-tailed) & .000 & 346 \\
& $\mathrm{~N}$ & 346 & \\
\hline
\end{tabular}

Source: Data processing results, 2019

For more details, the relationship between the two independent variables can be explained as follows: 


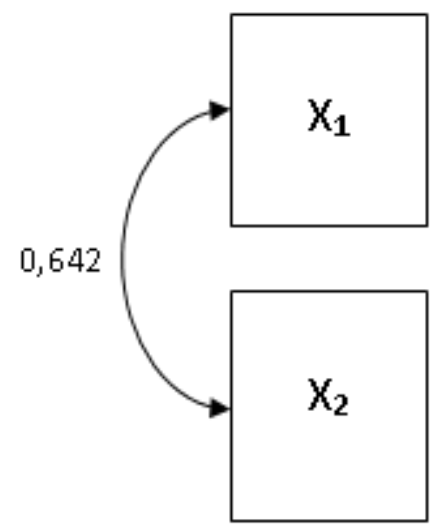

Figure 1. The Relationship between Shopping Motives $\left(\mathrm{X}_{1}\right)$ and Store Attributes $\left(\mathrm{X}_{2}\right)$

From the analysis, the correlation coefficient between the independent variables, namely shopping motive $\left(\mathrm{X}_{1}\right)$ and store attributes $\left(\mathrm{X}_{2}\right)$, can be assessed as 0.642 . Thus the shopping motive $\left(\mathrm{X}_{1}\right)$ with store attributes $\left(\mathrm{X}_{2}\right)$ has a strong and unidirectional relationship because the value is positive.

\section{Path Analysis}

Based on the results of data processing using SPSS 16, path coefficients were obtained for each shopping motive variable $\left(\mathrm{X}_{1}\right)$ and store attributes $\left(\mathrm{X}_{2}\right)$ on purchasing decisions $(\mathrm{Y})$. The results of this analysis can be seen in Table 4 .

Table 4

Path Coefficient

\begin{tabular}{|c|c|c|c|c|c|}
\hline \multirow[t]{2}{*}{ Coefficients $^{\mathrm{a}}$} & & & \multirow[b]{2}{*}{$\begin{array}{l}\text { Standardized } \\
\text { Coefficients }\end{array}$} & \multirow[b]{3}{*}{$\mathrm{T}$} & \multirow[b]{3}{*}{ Sig. } \\
\hline & \multicolumn{2}{|c|}{ Unstandardized Coefficients } & & & \\
\hline Model & $\mathrm{B}$ & Std. Error & Beta & & \\
\hline 1 (Constant) & 10.681 & 2.265 & & 4.715 & .000 \\
\hline Shopping Motives & .347 & .050 & .341 & 6.927 & .000 \\
\hline Store Attributes & .449 & .049 & .448 & 9.111 & .000 \\
\hline
\end{tabular}

a. Dependent Variable: Purchase Decision

Source: Results of data processing, 2019

The table shows the value of the path coefficient between the shopping motive variable and store attributes on purchasing decisions. The path coefficient values are respectively described as follows:

1) The shopping motive variable path coefficient $\left(\mathrm{X}_{1}\right)$ on the purchasing decision variable $(Y)$

Based on Table 4, the path coefficient for the shopping motive variable $\left(\mathrm{X}_{1}\right)$ on the purchasing decision variable $(\mathrm{Y})$ is 0.341 . This shows that the direct influence of the shopping motive variable $\left(\mathrm{X}_{1}\right)$ on the purchasing decision variable $(\mathrm{Y})$ is 0.341 so that the equation $\mathrm{Y}=0.341 \mathrm{X} 1$ is obtained.

The direct effect of variable $\mathrm{X}_{1}$ on variable $\mathrm{Y}$ can be described in Figure 2.

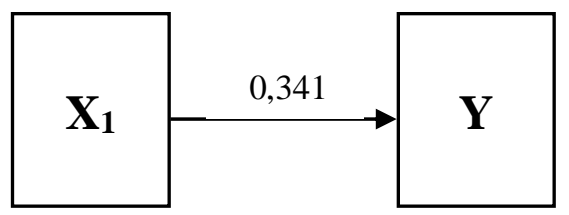

Figure 2

Partial Influence of Shopping Motive $\left(\mathrm{X}_{1}\right)$ on Purchasing Decisions (Y)

2) Store attribute variable path coefficient $\left(\mathrm{X}_{2}\right)$ on purchasing decision variable $(\mathrm{Y})$ 
Based on Table 4, the path coefficient for the store attribute variable $\left(\mathrm{X}_{2}\right)$ on the purchase decision variable (Y) is 0.448 . This shows that the direct effect of the store attribute variable $\left(\mathrm{X}_{2}\right)$ on the purchase decision variable $(\mathrm{Y})$ is 0.448 so that the equation $\mathrm{Y}=0.448 \mathrm{X}_{2}$ is obtained.

The direct effect of variable $\mathrm{X}_{2}$ on variable $\mathrm{Y}$ can be described in Figure 3.

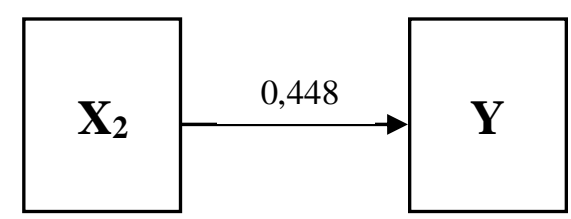

Figure 3. Partial Influence of Store Attributes $\left(\mathrm{X}_{2}\right)$ on Purchasing Decisions (Y)

The direct effect of variables $\mathrm{X} 1$ and $\mathrm{X} 2$ on variable $\mathrm{Y}$ can be described in Figure 4.

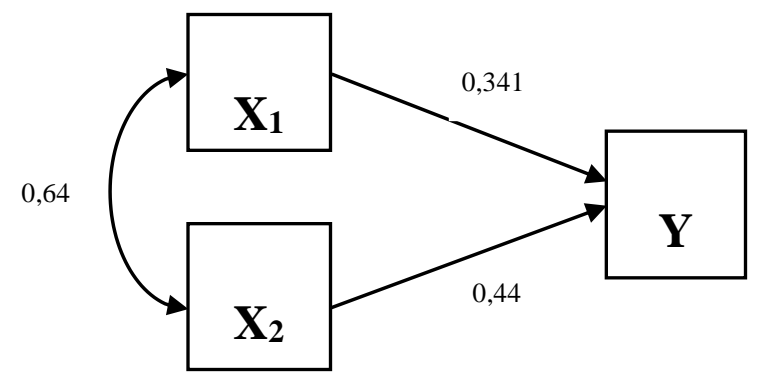

Figure 4. Direct Effect of Variables $\mathrm{X}_{1}$ and $\mathrm{X}_{2}$ on Variable $\mathrm{Y}$

Based on Figure 4, it shows that the amount of the associative positive degree or the variable path coefficient of the store attribute variable (0.448) is higher than the shopping motive variable (0.341), which means that store attributes (X2) have more influence on purchasing decisions (Y) than shopping motives (X1). The path equation is as follows:

$$
\mathrm{Y}=0.341 \mathrm{X} 1+0.448 \mathrm{X} 2+\rho \mathrm{y} \varepsilon 1
$$

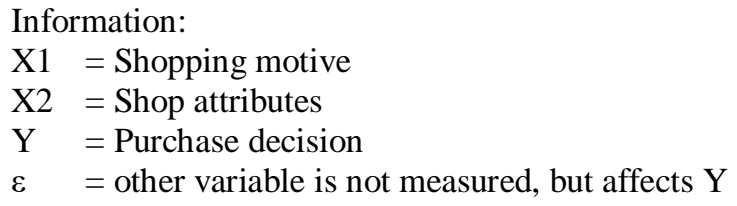

3) The effect of variable $X$ on variable $Y$

The direct and indirect effects simultaneously of the shopping motive variable (X1) and store attributes (X2) on purchasing decisions ( $\mathrm{Y}$ ) are as follows:

a. Effect of X1 on $\mathrm{Y}$

The influence of the shopping motive (X1) on purchasing decisions $(\mathrm{Y})$ can be seen in Table 5.

Table 5

Effect of Shopping Motive $\left(\mathrm{X}_{1}\right)$ on Purchasing Decisions (Y)

\begin{tabular}{|c|l|l|l|}
\hline Variable & Path Analysis Interpretation & Calculation & Magnitude of Influence \\
\hline \multirow{3}{*}{$\mathrm{X}_{1}$} & Direct influence to $\mathrm{Y}$ & $0,341^{2}$ & 0,116 \\
\cline { 2 - 4 } & Indirect influence $\mathrm{X}_{2}$ to $\mathrm{Y}$ & $\begin{array}{l}0,341 \times 0,642 \times \\
0,448\end{array}$ & 0,098 \\
\hline \multicolumn{2}{|l|}{} & 0,214 \\
\hline
\end{tabular}

Source: Results of data processing, 2013 
Table 5 shows that the influence of the shopping motive variable $\left(\mathrm{X}_{1}\right)$ on purchasing decisions $(\mathrm{Y})$ is 0.214 or $21.4 \%$.

b. Effect of $\mathrm{X}_{2}$ on $\mathrm{Y}$

The effect of store attributes $\left(\mathrm{X}_{2}\right)$ on purchasing decisions $(\mathrm{Y})$ can be seen in Table 6 below.

Table 6

The Influence of Shop Attributes $\left(\mathrm{X}_{2}\right)$ on Purchasing Decisions (Y)

\begin{tabular}{|l|l|l|l|}
\hline Variable & Path Analysis Interpretation & Calculation & Magnitude of Influence \\
\hline \multirow{3}{*}{$\mathrm{X}_{2}$} & Direct influence to Y & $0,448^{2}$ & 0,201 \\
\cline { 2 - 4 } & Indirect influence $\mathrm{X}_{2}$ to $\mathrm{Y}$ & $\begin{array}{l}0,341 \times 0,642 \times \mathrm{x} \\
0,448\end{array}$ & 0,098 \\
\hline Total & & 0,299 \\
\hline
\end{tabular}

Source: Results of data processing, 2019

Table 6 shows that the effect of store attribute variables $\left(\mathrm{X}_{2}\right)$ on purchasing decisions $(\mathrm{Y})$ is 0.299 or $29.9 \%$.

c. Effect of $\mathrm{X} 1$ and $\mathrm{X} 2$ on $\mathrm{Y}$

The influence of shopping motives $\left(\mathrm{X}_{1}\right)$ and store attributes $\left(\mathrm{X}_{2}\right)$ on purchasing decisions $(\mathrm{Y})$ can be seen in Table 7 below.

Table 7

The Influence of Shopping Motives $\left(\mathrm{X}_{1}\right)$ and Store Attributes $\left(\mathrm{X}_{2}\right)$ on Purchasing Decisions $(\mathrm{Y})$

\begin{tabular}{|l|l|l|l|l|l|}
\hline \multirow{2}{*}{ Variable } & \multirow{2}{*}{$\begin{array}{l}\text { Path } \\
\text { Coefficient }\end{array}$} & $\begin{array}{l}\text { Direct } \\
\text { Influence }\end{array}$ & \multicolumn{2}{|l|}{ Indirect Influence } & Subtotal \\
\cline { 3 - 5 } & & $\mathrm{X} 1$ & $\mathrm{X} 2$ & Influence \\
\hline $\mathrm{X}_{1}$ & 0,341 & 0,116 & ---- & 0,098 & 0,214 \\
\hline $\mathrm{X}_{2}$ & 0,448 & 0,201 & 0,098 & ----- & 0,299 \\
\hline Total & \multicolumn{4}{|l}{} & 0,513 \\
\hline
\end{tabular}

Source: Results of data processing, 2019

Table 7 shows that the total influence caused by shopping motives $\left(\mathrm{X}_{1}\right)$ and store attributes $\left(\mathrm{X}_{2}\right)$ on purchasing decisions $(\mathrm{Y})$ is 0.513 or $51.3 \%$. The effect of other variables outside the model is $1-0.513$ $=0.487$ or $48.7 \%$.

Table 8

Model Summary ${ }^{\mathrm{b}}$

\begin{tabular}{lllll}
\hline Model & $\mathrm{R}$ & R Square & Adjusted R Square Std. Error of the Estimate \\
\hline 1 & $.716^{\mathrm{a}}$ & .513 & .510 & 5.41517
\end{tabular}

a) Predictors: (Constant), Shop Attributes, Shopping Motive

b) Dependent Variable: Buying decision

Source: Data processing results, 2019

Based on Table 8, shows that the coefficient of determination $\left(\mathrm{R}_{2}\right)$ is 0.513 , meaning $51.3 \%$, the purchasing decision variable $(\mathrm{Y})$ can be explained by the shopping motive variable $(\mathrm{X} 1)$ and the store attribute $\left(\mathrm{X}_{2}\right)$, or it can be interpreted that the shopping motive $\left(\mathrm{X}_{1}\right)$ and store attributes $\left(\mathrm{X}_{2}\right)$ contributed to purchasing decisions $(\mathrm{Y})$ by $51.3 \%$, while the remaining $48.7 \%$ was the contribution of other variables $(\varepsilon)$ which were not examined. 


\section{Hypothesis test}

\section{Correlation between Shopping Motives $\left(X_{1}\right)$ and Store Attributes $\left(X_{2}\right)$}

Hypothesis testing of the relationship between shopping motives $\left(\mathrm{X}_{1}\right)$ and store attributes $\left(\mathrm{X}_{2}\right)$ was carried out using the $t$ statistical test, namely the following formula (M.B.A, 2011).

Known:

$$
t=\frac{r \sqrt{n-2}}{\sqrt{1-r^{2}}}
$$

$$
\begin{array}{rc}
r & =0,642 \\
\mathrm{n} & =346 \\
\text { Therefore: } & \\
t= & \frac{0,642 \sqrt{346-2}}{\sqrt{1-0,642^{2}}} \\
t & =\frac{0,642(18,547)}{\sqrt{1-0,412}} \\
t & =\frac{11,907}{0,767} \\
t & =15,524
\end{array}
$$

The price of $\mathrm{t}$ count above is then compared with $\mathrm{t}$ table, at an error rate of $5 \%, \mathrm{db}=\mathrm{n}-2=346-2=344$, then the obtained $\mathrm{t}$ table $=1.960$. Thus it is known that $\mathrm{t}$-count $(15.524)>\mathrm{t}$-table $(1.960)$, it can be stated that $\mathrm{H} 0$ is rejected, meaning that there is a significant relationship between shopping motive $\left(\mathrm{X}_{1}\right)$ and store attributes $\left(\mathrm{X}_{2}\right)$.

\section{The hypothesis of Partial Influence of Variables}

The analysis of the partial effect of the hypothesis between each independent variable on the dependent variable is as follows.

a) The hypothesis of the partial influence of shopping motives $\left(\mathrm{X}_{1}\right)$ on purchasing decisions $(\mathrm{Y})$

The effect of shopping motive $\left(\mathrm{X}_{1}\right)$ partially on purchasing decisions $(\mathrm{Y})$ can be seen through statistical testing using the following hypothesis:

H0: $\rho y x 1=0$ There is no influence of the shopping motive on purchasing decisions

H1: $\rho y x 1 \neq 0$ There is an influence of the shopping motive on purchasing decisions

Test criteria: Reject $\mathrm{H} 0$ if Sig. $<\alpha$ or $\mathrm{t}$-count $>\mathrm{t}$-table

For the shopping motive $\left(\mathrm{X}_{1}\right)$ partially towards purchasing decisions $(\mathrm{Y})$ with a significant level $(\alpha)=5 \%$, degree of freedom $(\mathrm{df})=\mathrm{n}-2=346-2=344$, the obtained $\mathrm{t}$-table $=1.960$. Based on Table 4 shows that $\mathrm{t}-$ count $=6.927$ and Sig. 0,000. The partial effect of $X_{1}$ on $Y$ is shown in the following Table 9 .

Table 9

Partial Influence of Shopping Motive $\left(\mathrm{X}_{1}\right)$ on Purchasing Decisions (Y)

\begin{tabular}{llllll}
\hline Structural & Sig. & $\alpha$ & $\mathrm{t}$-count & $\mathrm{t}$-table & Conclusion \\
\hline pyx $_{1}$ & 0,000 & 0,05 & 6,927 & 1,960 & $\mathrm{H}_{0}$ rejected \\
\hline
\end{tabular}

Source: Data processing results, 2019

Table 9 shows that the Sig. $(0.000)<\alpha(0.05)$ and t-count $(6.927)>$ t-table (1.960), then $\mathrm{H} 0$ is rejected. Thus it can be concluded that the shopping motive has a partial effect on purchasing decisions.

b) The hypothesis of the partial effect of store attributes $\left(\mathrm{X}_{2}\right)$ on purchasing decisions $(\mathrm{Y})$

The partial effect of store attributes $\left(\mathrm{X}_{2}\right)$ on purchasing decisions $(\mathrm{Y})$ can be seen through statistical testing using the following hypothesis:

H0: pyx $2=0$ There is no effect of store attributes on purchasing decisions 
H1: $\rho y x 2 \neq 0$ There is an effect of store attributes on purchasing decisions

Test criteria: Reject $\mathrm{H} 0$ if Sig. $<\alpha$ or t-count $>\mathrm{t}$-table

For store attributes $\left(\mathrm{X}_{2}\right)$ partially towards purchasing decisions $(\mathrm{Y})$ with a significant level $(\alpha)=5 \%$, degree of freedom $(\mathrm{df})=\mathrm{n}-2=346-2=344$ obtained $\mathrm{t}$ table $=1.960$. Based on the table 4.59 above, it shows that $\mathrm{t}-$ count $=9,111$ and Sig. 0,000. The partial effect of $X_{2}$ on $Y$ is shown in the following Table 10 .

Table 10

Partial Influence of Shop Attributes $\left(\mathrm{X}_{2}\right)$ on Purchasing Decisions ( $\mathrm{Y}$ )

\begin{tabular}{|c|c|c|c|c|c|}
\hline Structural & Sig. & $\alpha$ & $\mathrm{t}$-count & $\mathrm{t}$-table & Conclusion \\
\hline$\rho \mathrm{yx}_{2}$ & 0,000 & 0,05 & 9,111 & 1,960 & $\mathrm{H}_{0}$ rejected \\
\hline
\end{tabular}

Source: Data processing results, 2019

Table 9 shows that the Sig. $(0.000)<\alpha(0.05)$ and t-count $(9,111)>t$ table $(1,960)$, then H0 is rejected. Thus it can be concluded that store attributes have a partial effect on purchasing decisions.

\section{Simultaneous Variable Effect Hypothesis}

The effect of shopping motives $\left(\mathrm{X}_{1}\right)$ and store attributes $\left(\mathrm{X}_{2}\right)$ simultaneously (overall) on purchasing decisions $(\mathrm{Y})$ can be seen through statistical testing using the following hypothesis:

H0: pyx $1 \times 2=0$ There is no influence of shopping motives and store attributes on purchasing decisions

H1: pyx $1 \times 2 \neq 0$ There is an influence of shopping motives and store attributes on purchasing decisions

Test criteria: Reject $\mathrm{H} 0$ if Sig. $<\alpha$ or f-count $>$ f-table

For shopping motive $\left(\mathrm{X}_{1}\right)$ and store attributes $\left(\mathrm{X}_{2}\right)$ simultaneously on purchasing decisions $(\mathrm{Y})$ with a significant level $(\alpha)=5 \%$, degree of freedom $(\mathrm{df})=\mathrm{n}-2=346-2=344$ obtained $\mathrm{f}$-table $=3,02$. While $\mathrm{f}$-count can be seen from the Table 11.

Table 11

Results of the F-value Calculation ANOVA ${ }^{\mathrm{b}}$

\begin{tabular}{llllll}
\hline Model & Sum of Squares & df & \multicolumn{2}{l}{ Mean Square $\mathrm{F}$} & Sig. \\
\hline 1 Regression & 10584.258 & 2 & 5292.129 & 180.471 & $.000^{\mathrm{a}}$ \\
Residual & 10058.143 & 343 & 29.324 & & \\
Total & 20642.400 & 345 & & & \\
\hline
\end{tabular}

a. Predictors: (Constant), Shop Attributes, Shopping Motive

b. Dependent Variable: Purchase Decision

Source: Results of data processing, 2019

Based on Table 10, shows that $\mathrm{f}$-count $=180.471$ and Sig. $=0,000$. The simultaneous effect of $\mathrm{X}_{1}$ and $\mathrm{X}_{2}$ on $\mathrm{Y}$ is shown in the following Table 12.

Table 12

Simultaneous Influence of Shopping Motive (X1) and Store Attributes (X2) on Purchasing Decisions (Y)

\begin{tabular}{lccccc}
\hline Structural & Sig. & $\alpha$ & $\mathrm{t}_{\text {-count }}$ & $\mathrm{t}_{\text {-table }}$ & Conclusion \\
\hline py $\mathrm{x}_{1} \mathrm{x}_{2}$ & 0,000 & 0,05 & 180,471 & 3,02 & $\mathrm{H}_{0}$ rejected \\
\hline \multicolumn{5}{r}{ Sumber: Data processing results, 2019} \\
\hline
\end{tabular}

Table 12 shows that the Sig. $(0.000)<\alpha(0.05)$ and f-count $(180.471)>$ t-table (3.02), then $\mathrm{H} 0$ is rejected. Thus it can be concluded that shopping motives and store attributes have a simultaneous effect on purchasing decisions. 


\section{Conclusion}

Based on the data obtained from the research results, the researcher can provide a conclusion as follows.

1) Respondents to the shopping motive $\left(X_{1}\right)$ of Matahari Department Store Karawang consumers indicate that eight indicator measurements are in fairly agreeable criteria, namely, affordable prices, getting sensation and the inner satisfaction, being excited when shopping, shopping can relieve stress, shopping can eliminate boredom, acquiring new product knowledge, shopping to buy things for others, and shopping for discounted prices. Then seven measurement indicators are on the agreed criteria, namely shopping to get the products needed, shopping for quality products, good service, saving time, choosing products according to taste, spending time with friends/family, and shopping because of sales promotions

2) Respondents' responses regarding store attributes $\left(\mathrm{X}_{2}\right)$ at Matahari Department Store Karawang show that there is one indicator measurement that is on the criterion to disagree, namely the parking lot. Three measurement indicators are on fairly agreeable criteria, namely price suitability with quality, product diversity, and products following fashion developments. Then eleven measurement indicators are on the agreed criteria, namely escalators and changing rooms, strategic location, access to transportation for employees to provide clear information about products, employee friendliness, employee speed in serving, ease of transactions, the grouping of product types, store lighting, attractive store designs, and shop cleanliness.

3) Respondents' responses regarding the purchasing decision (Y) for Matahari Department Store Karawang consumers show that six indicator measurements are in quite agreeable criteria, namely shopping after seeing other people, information from friends/family, television advertisements, newspaper or magazine advertisements, usage before, and reference products. Then nine measurement indicators are on the agreed criteria, namely self-needs, radio advertisements, product catalogs, shop displays, considering product alternatives, determining alternative product options, buying after evaluating products, satisfaction, and reinvestment.

4) There is a correlation between shopping motives $\left(X_{1}\right)$ and store attributes $\left(X_{2}\right)$ with a correlation coefficient value of 0.642 and has a strong and unidirectional relationship because the value is positive.

5) There is a partial influence between shopping motives $\left(X_{1}\right)$ and store attributes $\left(X_{2}\right)$ on purchasing decisions (Y).

a) The partial effect of shopping motive $\left(\mathrm{X}_{1}\right)$ on purchasing decisions $(\mathrm{Y})$ is 0.341 .

b) The partial effect of store attributes $\left(\mathrm{X}_{2}\right)$ on purchasing decisions $(\mathrm{Y})$ is 0.448 .

Because $0.448>0.341$, it is stated that the store attribute variable contributes more to the purchase decision than the shopping motive variable.

c) The total effect of shopping motives $\left(\mathrm{X}_{1}\right)$ and store attributes $\left(\mathrm{X}_{2}\right)$ on purchasing decisions $(\mathrm{Y})$ is $51.3 \%$.

This shows that the shopping motive $\left(\mathrm{X}_{1}\right)$ and store attributes $\left(\mathrm{X}_{2}\right)$ have contributed to the purchase decision (Y) by $51.3 \%$, while the remaining $48.7 \%$ is the contribution of other variables $(\varepsilon)$ which are not studied.

Suggestion

Suggestions that can be considered by the company in connection with the research results can be described as follows.

1) Characteristics of respondents based on gender indicate the number of female consumers is more than male consumers. Matahari Department Store Karawang is expected to provide more items for women's needs such as clothes, bags, shoes, sandals, cosmetics, and others. Then supplement the male necessities to attract more male consumers.

2) Then the characteristics of respondents based on age show that most consumers are at the age <25 years, 2535, 36-45. In this case, Matahari Department Store Karawang is expected to provide and complete more items according to this age range.

3) Meanwhile, the characteristics of respondents based on occupation show that most consumers are private employees. In this case, Matahari Department Store Karawang is expected to provide and complete more goods with various prices and according to quality to attract consumers.

4) Based on the results of respondents' responses, there are indicators of shopping motives that are still lacking, namely affordable prices, gaining sensation and the inner satisfaction, being excited when shopping, shopping can relieve stress, shopping can relieve boredom, acquiring new product knowledge, shopping to buy goods for other people, and shopping for a discount. The suggestions from researchers are as follows: 
a) Matahari Department Store Karawang is expected to provide complete and diverse consumer products according to the latest trends with various price options so that it can provide knowledge about fashion, and can arouse consumer shopping enthusiasm, as well as provide a pleasant shopping experience.

b) Matahari Department Store Karawang is expected to provide shopping facilities that support the convenience of consumers so that consumers can forget about burdens or stress and eliminate boredom.

c) Matahari Department Store Karawang is expected to provide more frequent discounts to attract more consumers.

5) Based on the results of the respondents' responses, there are indicators of store attributes that are still lacking, namely parking space, namely the suitability of price with quality, product diversity, and products following fashion developments. The suggestions from researchers are as follows:

1) Matahari Department Store Karawang is expected to expand the parking lot by using unused empty spaces or areas such as the sides and back of the building.

2) Matahari Department Store Karawang is expected to continue to complete the completeness of its products, which are following the development of fashion.

6) Based on the results of respondents' responses, there are indicators of purchasing decisions that are still lacking, namely shopping after seeing other people, information from friends/family, television advertisements, newspaper or magazine advertisements, previous use, and reference products. The suggestions from researchers are as follows:

3) Matahari Department Store Karawang is expected to continue to improve the quality and fashion development of its products. So that people who use Matahari products will look fashionable and will stimulate other people to buy Matahari products.

4) Matahari Department Store Karawang is expected to continue to promote its products through advertising media regarding existing products or promos to attract consumers to come to the store.

\section{References}

Azizi, N. F. (2009). Pengaruh atribut toko terhadap perilaku konsumen dalam berbelanja di Bentar Dipayana Swalayan Blitar. Pengaruh atribut toko terhadap perilaku konsumen dalam berbelanja di Bentar Dipayana Swalayan Blitar/Nanang Fidrul Azizi.

Dearma, I. W. (2011, February 20). Pengaruh Motif Belanja dan Atribut Toko Terhadap Keputusan Pembelian Carrefour Plaza Medan Fair.

Eastlick, M. A., \& Feinberg, R. A. (1999). Shopping motives for mail catalog shopping. Journal of Business Research, 45(3), 281-290. https://doi.org/10.1016/S0148-2963(97)00240-3

Foster, B. (2008). Manajemen Ritel. Alfabeta. Bandung. hlm. 61. Chandra Dewi dan Nuryati. 2014. Pengaruh Kualitas PelayananTerhadap Kepuasan dan Minat Beli Konsumen dirumah Makan Boga-Bogi Surakarta. Informatika, 1(2).

Hunneman, A., Verhoef, P. C., \& Sloot, L. M. (2017). The moderating role of shopping trip type in store satisfaction formation. Journal of Business Research, 78, 133-142. https://doi.org/10.1016/j.jbusres.2017.05.012

Jackson, V., Stoel, L., \& Brantley, A. (2011). Mall attributes and shopping value: Differences by gender and generational cohort. Journal of retailing and consumer services, 18(1), 1-9. https://doi.org/10.1016/j.jretconser.2010.08.002

Kotler (2007). Manajemen Pemasaran Edisi Kedua Belas Jilid 1. Jakarta: PT. Indeks.

Kotler, P., \& Armstrong, G. (2008). Prinsip-Prinsip Pemasaran Jakarta. Penerbit Erlangga.

M.B.A, D. (2011). Dasar-Dasar Statistika. Bandung: Alfabeta.

Solomon, M. R., \& Panda, T. K. (2004). Consumer behavior, buying, having, and being. Pearson Education India.

Stoel, L., Wickliffe, V., \& Lee, K. H. (2004). Attribute beliefs and spending as antecedents to shopping value. Journal of Business Research, 57(10), 1067-1073. https://doi.org/10.1016/S0148-2963(03)00016-X

Sugiyono, P. D. (2012). Metode Penelitian Kuantitatif Kualitatif Dan R\&D (Vol. 8). Alfabeta. Bandung.

Sugiyono, P. D. (2013). Metode penelitian kuantitatif dan kualitatif dan R\&D [Quantitative and qualitative and R \& D research methods]. Bandung, Indonesia: Alfabeta.

Sumarwan, U. (2011). Perilaku konsumen: Teori dan penerapannya dalam pemasaran. Bogor: Ghalia Indonesia.

Sumarwan, U., Fachrodji, A., \& Nursal, A. (2011). Pemasaran Strategik Perspektif Value-Based Marketing \& Pengukuran Kinerja. PT Penerbit IPB Press.

Sutisna. (2003). Perilaku Konsumen dan Komunikasi Pemasaran. Bandung: PT Remaja Rosdakarya.

Umar, H. (2005). Metode Penelitian Skripsi Dan Tesis Bisnis. Jakarta: PT. Raja Grafindo Persada.

Utami, C. W. (2010). Manajemen Ritel_Strategi dan Implementasi Operasional Bisnis Ritel Modern Di Indonesia. 
Wong, Y. T., Osman, S., Jamaluddin, A., \& Yin-Fah, B. C. (2012). Shopping motives, store attributes and shopping enjoyment among Malaysian youth. Journal of retailing and Consumer Services, 19(2), 240-248. https://doi.org/10.1016/j.jretconser.2012.01.005 